\title{
EFFECTIVENESS OF INQUIRY-BASED LEARNING TOWARDS MASTERING THE CONCEPT OF UNSATURATED HYDROCARBONS IN UNDERGRADUATE STUDENTS
}

\author{
Helda Lupita Septyastuti ${ }^{1}$, Sutrisno ${ }^{1 *}$ and Hayuni Retno Widarti ${ }^{1}$ \\ ${ }^{1}$ Department of Chemistry, Universitas Negeri Malang, Jl. Semarang No. 5 Malang, 65145, \\ Indonesia \\ *E-mail: sutrisno.kimia@um.ac.id
}

Received: 16 October 2020; Accepted: 15 November 2020; Published: 31 December 2020

\begin{abstract}
Inquiry learning can be applied to chemistry learning at any level of education. This is according to the characteristics of chemistry, which is based on empirical evidence for real-world study. One of the topics studied in Organic Chemistry Lecture is an unsaturated hydrocarbon that discussed the structure, nomenclature, properties, manufacture, and usability. There are various models or strategies of inquiry for chemistry learning, especially guided inquiry. One of the guided inquiry-based chemistry learning strategy innovations is the $\mathrm{OE}_{3} \mathrm{R}$ (Orientation - Exploration - Explanation - Elaboration - Reflection) strategy for various education levels, high schools, and universities. This research aimed to determine the effectiveness of guided inquiry-based learning with $\mathrm{OE}_{3} \mathrm{R}$ strategy in undergraduate students' conceptual understanding of the Unsaturated Hydrocarbon concept. The research using a Quasi Experiment with a pretest-posttest control group design. Conceptual understanding with $\mathrm{OE}_{3} \mathrm{R}$ Strategy proven to be better than Expository Strategy. This can be seen from achieving minimum completeness criteria, which is $92.3 \%$ for $\mathrm{OE}_{3} \mathrm{R}$ and $72.2 \%$ for expository. It can also be seen from the $\mathrm{N}$-gain value for the $\mathrm{OE}_{3} \mathrm{R}$ Strategy $(0.43)$, which is significantly better than the Expository Strategy (0.27).
\end{abstract}

Keywords: conceptual understanding, inquiry-based learning, $\mathrm{OE}_{3} \mathrm{R}$ strategy, unsaturated hydrocarbon

DOI: http://doi.org/10.15575/jtk.v5i2.9078

\section{INTRODUCTION}

Chemistry is a science that focuses on nature, reactions changes, and its energy that accompanies compositions and structures. Based on these characteristics, chemistry has various concepts: abstract concepts, concrete concepts, and defined concepts. Organic Chemistry studies at the university level discuss several topics. One of them is unsaturated hydrocarbons. Unsaturated hydrocarbon topics are alkenes, alkynes, and benzenes, focusing on structures, nomenclatures, natures, manufacture, and usefulness. This topic has all three characteristics of the concept. To understand the concept well, the three characteristics of the concept must be combined in its entirety.
A comprehensive understanding of the chemistry learning process concepts involves three levels of representation: macroscopic, submicroscopic, and symbolic (Talanquer et al., 2011). Macroscopic representation is a chemical representation through real observation of a phenomenon that can be sensed. Submicroscopic representation is a chemical representation that explains a reviewed phenomenon from the molecular level. Symbolic representation is a chemical representation toward converting a substance into chemical formulas, reaction equality, or charts.

Understanding the concept of chemistry can be seen based on students' ability to connect and transfer these three-representations into different situations. For instance, in one of 
petroleum, it is solar. In macroscopic representations, it is understood that solar is liquid and flammable. Sub-microscopic representations are in the perfect combustion diesel process, i.e., solar reactions with oxygen that produces carbon dioxide and moisture. This level involves the concept of reasoning the disconnection of hydrocarbon chains in a diesel by oxygen molecules and establishing new compounds of carbon dioxide gas and water vapor. Symbolic representations can be written in reaction equations, there is $2 \mathrm{C}_{12} \mathrm{H}_{26}(\mathrm{l})+37 \mathrm{O}_{2}(\mathrm{~g}) \rightarrow$ $24 \mathrm{CO}_{2}(\mathrm{~g})+26 \mathrm{H}_{2} \mathrm{O}(\mathrm{I})$.

In order to be able to understand the macroscopic, sub-microscopy, and symbolic representations fully, strategic movement is needed. This movement can be seen as six domains of science, namely concepts, processes, applications, attitudes, creativity, and the nature of science (Enger et al., 2009). The role of the science domain contains elements of exploring and investigating how scientists work and think. Thus from this domain, it is assumed that knowledge is found and obtained, so the science process is frequently designed as inquiry skills.

Inquiry learning is an observed based learning process that invites students' to carry out scientific processes as scientist study nature, allowing them to use all their competencies to discover the concept itself (Nugraha et al., 2016; Panasan et al., 2012). Inquiry teaches skills such as problem-solving, critical thinking, integrating science process skills, learning through groups cooperatively, using high-level thinking skills, manipulating and measuring skills, using mathematical operation, and communicating (Iskandar, 2015).

Based on those skills that can be trained above, students' are required to be active in learning. In accordance with the characteristics of the science learning process, there are (1) engage in scientific questions; (2) prioritize evidence; (3) formulate explanations based on evidence; (4) evaluate the explanation in accordance with scientific concepts; and (5) communicate and justify claims of knowledge (NRC, 2000). In learning, the teacher acts as a facilitator during the learning process to ask about concepts or problems related to the learning material. In addition, teachers should be able to create a conducive environment for learning.

This learning model invites students' to understand science through scientific methods aiming to understand the concept that is informative and involves student activities in building an understanding of concepts (Magfirah et al., 2019). Chemistry learning involves students' activities and skills to understand better the knowledge students' want to know (Haury, 2015). Inquiry-based learning has to involve each learner in his/her meaningful, appropriate, and truth-based learning activities so that learners will understand the true nature of science as a process, product, and attitude (Masruroh et al., 2019). Inquiry learning activities focus on the essential concepts and processes to encourage and foster a deep understanding of the material (Alhudaya et al., 2018).

There are various models of guided chemical learning strategies, including (1) Process Oriented Guided Inquiry Learning (POGIL) (Hanson et al., 2006); (2) The Model Observe Reflect Explain (MORE) Thinking Frame (Mattox et al., 2006); (3) Five Stages according to Wenning: ObservationManipulation-Generalization-Verification-

Application (Wenning, 2005); (4) Five Stages according to Pedaste, i.e., OrientationConceptualization-Investigation-ConclusiveDiscussion (Manoli et al., 2015); and (5) $\mathrm{OE}_{3} \mathrm{R}$ Strategy (Sutrisno, 2018).

Based on several studies, it shows that guided inquiry learning can improve conceptual understanding and learning achievements in chemistry (Lin et al., 2016), improve mastery of concepts and attitudes towards science (Zeidan et al., 2015), provide significant results on the achievement of mastery of learning concepts (Supasorn et al., 2014), and improve students' learning understanding of chemistry, skills, and attitudes attitudes (Sesen et al., 2013).

The inquiry-based learning strategy implemented in this research is executed 
based on three representation and six science domains, namely the $\mathrm{OE}_{3} \mathrm{R}$ Strategy. The $\mathrm{OE}_{3} \mathrm{R}$ strategy stands for the initial letter of each stage, namely Orientation-ExplorationExplanation-Elaboration-Reflection.

The learning stages with the $\mathrm{OE}_{3} \mathrm{R}$ Strategy in terminology are easy to understand and reflect the learning activities carried out to be convenient to implement. The purpose of this study is to find out the effectiveness of inquirybased learning guided by the $\mathrm{OE}_{3} \mathrm{R}$ Strategy towards mastering student concepts on the unsaturated hydrocarbons topic.

\section{RESEARCH METHOD}

The design of this study uses Quasi Experiment with pre-test post-test control group design research model. This research was conducted on students' of the bachelor Chemistry Study Program, Department of Chemistry, FMIPA of Universitas Negeri Malang in September - October 2019. The samples were taken using convenience sampling techniques. This study has two groups, namely the learning experiment group using the $\mathrm{OE}_{3} \mathrm{R}$ Strategy and the control group with the Expository Strategy. The research model can be seen in Table 1 .

Table 1. Pre-test Post-test Only Control Group Design

\begin{tabular}{|c|c|c|c|}
\hline Groups & Pre-test & Treatments & Post-test \\
\hline Experiment & $\mathrm{O}_{1}$ & $\mathrm{X}_{1}$ & $\mathrm{O}_{1}$ \\
\hline Control & $\mathrm{O}_{1}$ & $\mathrm{X}_{2}$ & $\mathrm{O}_{1}$ \\
\hline
\end{tabular}

Descriptions:

$\mathrm{X}_{\mathrm{I}}$ : Learning Process with $\mathrm{OE}_{3} \mathrm{R}$ Strategy

$\mathrm{X}_{2}$ : Learning Process with Expository Strategy

$\mathrm{O}_{1}$ : Early Test before treatment and test after treatment in $\mathrm{OE}_{3} \mathrm{R}$ Strategy and Expository Strategy

This research uses two types of instruments; there are treatment instruments and measurement instruments. Treatment instruments consist of RPPS (Semester Learning Implementation Plan) and MFI (Student Worksheet). Meanwhile, measurement instruments include a concept mastery test instrument that amounts to 45 items of selected-response type test with multiple-choice, reasoned multiple-choice, and completely reasonable. Before use, the instrument was tested for the validity of its contents by two chemistry lecturers of FMIPA UM. The validity of the assessment instrument's contents is 88.52 , which indicates that the assessment instrument has excellent validity.

The data was gained from pre-test and posttest results in the experimental group and control group. To find out the difference in students' mastery concept hypothesis test was conducted using a t-test. However, the first performed prerequisite test analysis is a normality test and homogeneity test. The improvement of student concept mastery in both groups is determined using the analysis of the $\mathrm{N}$-gain score.

\section{RESULT AND DISCUSSION}

The data used to determine the difference in students' mastery concepts was obtained from post-test scores on unsaturated hydrocarbons topics (alkenes, alkynes, and benzene). The detailed scoring result of students' mastering concepts in both groups can be found in Table 2.

Table 2. The Scoring Result of Students' Mastery Concepts on Unsaturated Hydrocarbon Topic

\begin{tabular}{|l|c|c|c|c|c|}
\hline \multicolumn{1}{|c|}{ Groups } & Averages & $\begin{array}{c}\text { Students' with a score above } \\
\text { the pass minimum value } \\
(\mathbf{\geq 5 5 )}\end{array}$ & $\begin{array}{c}\text { Maximum } \\
\text { Score }\end{array}$ & $\begin{array}{c}\text { Minimum } \\
\text { Score }\end{array}$ & S $_{\text {D }}$ \\
\hline Experiment & 67.54 & 24 & 83 & 53 & 8.48 \\
\hline Control & 57.33 & 13 & 72 & 33 & 9.57 \\
\hline
\end{tabular}


Before the hypothesis test, the analysis's prerequisite test is carried out in advance, namely the homogeneity test and normality test. The test results of homogeneity and normality can be seen in Table 3 . In addition, two average similarity tests were also conducted, presented in Table 4.

Table 3. The Result of Homogeny and Normality Tests in Students' Mastery Concepts

\begin{tabular}{|l|c|c|}
\hline \multirow{2}{*}{ Groups } & \multicolumn{2}{|c|}{ Significance Score } \\
\cline { 2 - 3 } & $\begin{array}{c}\text { Normality } \\
\text { Test }\end{array}$ & $\begin{array}{c}\text { Homogeny } \\
\text { Test }\end{array}$ \\
\hline Experiment & 0.872 & 0.994 \\
\hline Control & 0.756 & 0.29 \\
\hline
\end{tabular}

Table 4. The Result of Experimental Similarity between Two Averages of Students' Mastery Concepts

\begin{tabular}{|l|l|l|}
\hline \multicolumn{1}{|c|}{ Groups } & $\begin{array}{l}\text { Significance } \\
\text { Score }\end{array}$ & \multicolumn{1}{|c|}{ Conclusion } \\
\cline { 1 - 1 } Experiment & \multirow{2}{*}{0.535} & $\begin{array}{l}\text { The pre-test data } \\
\text { of mastering } \\
\text { Concepts is not } \\
\text { different in the } \\
\text { two groups. }\end{array}$ \\
\hline
\end{tabular}

Normality test results obtained the significance value of both groups greater than 0.05 . The value indicates that the data distribution of the experimental group as well as the control group, is normal. Homogeneity test results obtained the significance value of both groups greater than 0.05 . The value indicates that the experimental group's data distribution and the control group has a homogeneous variant.

The similarity test of the two average students' mastery concepts is used to find out whether the pre-test scores of the two groups are different or not. The similarity test results of two average students' mastery concepts obtained a significance value greater than 0.05 . The value indicates that there is no difference in concept mastery pre-test data.

Differences in conceptual mastery are determined by parametric statistical analysis (t-test) with a significance of 0.05 . Hypothetical test results are presented in Table 5.

Table 5. The Data Result of t-test in Mastery Concepts

\begin{tabular}{|c|c|c|}
\hline Variables & Score t-count & Score t-table \\
\hline $\begin{array}{l}\text { Mastering } \\
\text { Concepts }\end{array}$ & 3.725 & 1.682 \\
\hline
\end{tabular}

Based on the results of the t-test above shows that the research hypothesis is accepted. Thus, there are differences in students' mastery concepts with $\mathrm{OE}_{3} \mathrm{R}$ Strategy and Expository Strategy. In addition, the difference was shown from the average score with a superior $\mathrm{OE}_{3} \mathrm{R}$ Strategy (67.54) compared to the Expository Strategy (57.33), and the number of students' who scored above the minimum pass score for the $\mathrm{OE}_{3} \mathrm{R}$ Strategy was $92.31 \%$. In comparison, the Expository Strategy was $72.22 \%$. These results are in accordance with Imas et al. research that the $\mathrm{OE}_{3} \mathrm{R}$ Strategy has a good impact on mastery of the concept of learning (Imas et al., 2020).

The data used to determine the improvement of students' mastery concept was obtained from pre-test and post-test values on the unsaturated hydrocarbons topic (alkenes, alkynes, and benzene). The improvement of students' mastery concept is determined using $\mathrm{N}$-gain score analysis. $\mathrm{N}$-gain score test result data can be seen in Table 6 .

Table 6. The Data Result of $\mathbf{N}$-gain score in Students' Mastery Concepts

\begin{tabular}{|c|c|c|c|c|}
\hline Groups & Pre-Test Averages & Post-Test Average & Gain Score & Characteristics \\
\hline Experiment & 41.42 & 67.54 & 0.43 & Middle \\
\hline Control & 41 & 57.33 & 0.27 & Low \\
\hline
\end{tabular}

Based on the analysis results, it is obtained an average value of $\mathrm{N}$-gain with the $\mathrm{OE}_{3} \mathrm{R}$ Strategy of 0.43 while the Expository Strategy of 0.27 . The analysis of average $\mathrm{N}$-gain values showed that the increase in mastery of student concepts with the $\mathrm{OE}_{3} \mathrm{R}$ Strategy falls into the medium category. In the Expository Strategy, the improvement of students' mastery concept belongs to the low category. These results are in line with Sutrisno et al., who says that the 
$\mathrm{OE}_{3} \mathrm{R}$ Strategy is superior in improving learning mastery concepts to Conventional Strategies (Sutrisno et al., 2018). Inquirybased learning emphasizes the learning process using the scientific steps in the science process skills so that the mastery concept can be well-formed (Kurniawati et al., 2016).

The application of learning strategies with certain syntax/stages requires students' to actively conduct the learning process to impact the formation of the concept of material so that the mastery of the student concept will be better when there are certain learning strategies. At the students' training orientation stage, it is aimed students' to associate new information received with relevant concepts that have been contained in their cognitive structure to stimulate students' curiosity towards the concept. Exploration phase, making students' active to collect data, facts, the information in their cognitive structure. This causes an imbalance in the processing of information so that students' try to interpret the data that has been obtained into new knowledge for them. At the explanation stage, students' develop and analyze concepts based on facts, data, information obtained from the exploration stage so that a conclusion is obtained to the concept studied (Rahmawati et al., 2018). The activity will provide meaningful learning and help students' to understand the concept as a whole (Widarti et al., 2018).

The $\mathrm{OE}_{3} \mathrm{R}$ strategy is one of the inquiry-based learning strategies. Inquiry-based learning can train students' to observe, collect, analyze, synthesize, and make conclusions. It has the impact to develop problem-solving skills and make learning more meaningful (Andrini, 2016; Glackin et al., 2017; Villagonzalo, 2014). The exploration and discovery phase of concepts in inquiry-based learning helps students' find relevant information from various sources. It directs them to find concept patterns based on the results of the information obtained to help develop concept mastery (Hanson et al., 2006). These steps in inquiry-based learning can encourage learners to improve their thinking skills (Sulistyowati et al., 2020). The application of inquiry-based learning also makes learners get a concrete learning experience by interacting and observing objects directly, so learning becomes more interesting (Khanifah et al., 2012).

The $\mathrm{OE}_{3} \mathrm{R}$ strategy was developed based on hybridization in three levels of representation and six domains of science. Three levels of representation (macroscopic, submicroscopy, and symbolic) can connect students' understanding of chemical concepts, then the interconnection of the three representations can help improve students' conceptual understanding. Based on six science domains, concepts are central to science, and students' understanding is essential to success in learning. In science learning, especially chemistry, physical activity is required in lab-based or non-lab investigation processes to understand concepts (Sutrisno et al., 2020). The result of the investigation process can be constructed into a whole concept. At the elaboration stage, training the concepts that have been obtained to be applied to new problems in the same context. Besides that, the concept's application is verification of students' attitudes toward the learning process. In addition, students' have also had creativity and the nature of science to apply the concept overall. This is where the implications of the stage of reflection. Several studies have also shown that inquiry-based learning has a positive influence on improving the mastery of learning science process concepts and skills (Alhudaya et al., 2018; Ambarsari et al., 2013; Simsek et al., 2010), having a good impact on higher-order thinking skills (HOTS) and LOTS (lower-order thinking skills) of learners (Izzatin et al., 2018; Putri et al., 2018; Sutrisno, et al., 2020), and improving understanding of science and academic achievement (Azizmalayeri et al., 2012; Chan et al., 2012; Margunayasa et al., 2019). 


\section{CONCLUSION}

Inquiry-based learning with the $\mathrm{OE}_{3} \mathrm{R}$ Strategy effectively implements students' mastery concept on unsaturated hydrocarbons topics (alkenes, alkynes, and benzene). The number of students' who scored above the minimum graduation rate with the $\mathrm{OE}_{3} \mathrm{R}$ Strategy was 92.3\%, while in the Expository Strategy, it was $72.2 \%$. Similarly, there was an increase in concept mastery with an N-gain of 0.43 in the $\mathrm{OE}_{3} \mathrm{R}$ Strategy and 0.27 in the Expository Strategy. Based on this study's results, the $\mathrm{OE}_{3} \mathrm{R}$ Strategy is recommended as one of the inquiry-based learning strategies for the same learning topics or other topics, both in high school and college. 
Efectiveness of Inkuiri-based Learning towards Mastering the Concept of Unsaturated Hydrocarbons in Undergraduated Students

\section{REFERENCES}

Alhudaya, M. T., Hidayat, A., \& Koeshandayanto, S. (2018). Pengaruh Inkuiri Terbimbing terhadap Keterampilan Proses Sains dan Pemahaman Konsep Optik Siswa Kelas VIII. Jurnal Pendidikan: Teori, Penelitian, dan Pengembangan, 3, 1398-1404.

DOI: http://dx.doi.org/10.17977/jptpp.v3i 11.11747

Ambarsari, W. (2012). Penerapan Pembelajaran Inkuiri Terbimbing terhadap Keterampilan Proses Sains Dasar pada Pelajaran Biologi Siswa Kelas VIII SMP Negeri 7 Surakarta. Jurnal Pendidikan Biologi, 5 (1).

Retrieved from https://jurnal.uns.ac.id/bio/article/view/5 626

Andrini, V. S. (2016). The Effectiveness of Inquiry Learning Method to Enhance Students' Learning Outcome: A Theoretical and Empirical Review. Journal of Education and Practice, 7(3), 38-42.

DOI:10.2991/icomse-

17.2018 .28

Azizmalayeri, K., Mirshahjafari, E., Sharif, M., Asgari, M., \& Omidi, M. (2012). The Impact of Guided Inquiry Methods of Teaching on The Critical Thinking of High School Students'. Journal of Education and Practice, 3(10), 42-47. Retrieved from https://www.iiste.org/Journals/index.php /JEP/article/view/2530

Chan, K. Y. K., Yang, S., Maliska, M. E., \& Grunbaum, D. (2012). An Interdisciplinary Guided Inquiry on Estuarine Transport Using a Computer Model in High School Classrooms. 74(1), 26-33. https://doi.org/10.1525/abt.2012.74.1.7

Enger, S.K. \& Yager, R. E. (2009). Assessing Student Understanding in Science: $A$ Standard-Based K-12 Handbook. California: Corwin A SAGE Company.
Fraenkel, J. R., Wallen, N. E., \& Hyun, H. H. (1993). How to Design and Evaluate Research in Education (8th ed.). New York: McGraw-Hill.

Glackin, M., \& Harrison, C. (2018). Budding Biology Teachers: What Have Botanical Gardens Got to Offer Inquiry Learning. Journal of Biological Education, 52(3), 283-293.

https://doi.org/10.1080/00219266.2017. 1357648.

Hanson, D. M. (2006). Instructor's Guide to Process-Oriented Guided-Inquiry Learning. Lisle, IL: Pacific Crest.

Haury, D. L. (1993). Teaching Science through Inquiry. ERIC/CSMEE Digest.

Imas, A. F., Sutrisno, S., \& Widarti, H. R. W. R. (2020). $\quad \mathrm{OE}_{3} \mathrm{R}$ Strategy Implementation as an Innovation on Inquiry-Based Learning toward Redox Reaction Mastery. Jurnal IImu Pendidikan, 25(1), 43-49. https://doi/10.17977/jip

Iskandar, S. M. (2011). Pendekatan Pembelajaran Sains Berbasis Konstruktivis. Malang: Bayumedia Publishing.

Izzatin, M., \& Nurmala, R. (2018). Pembelajaran Berbasis Inquiry untuk Melatih Higher Order Thinking Skills (HOTS) Mahasiswa Pendidikan Matematika pada Mata Kuliah Metode Numerik. Edukasia: Jurnal Pendidikan, $5(2)$.

https://doi.org/10.35334/edu.v5i2.1007

Khanifah, S., Pukan, K. K., \& Sukaesih, S. (2012). Pemanfaatan Lingkungan Sekolah sebagi Sumber Belajar untuk Meningkatkan Hasil Belajar Siswa. Unnes Journal of Biology Education, 1(1), 66-73. Retrieved from https://studylibid.com/doc/1154239/1hubungan-pemanfaatan-lingkungansekolah-dan-hasil-belajar 
Efectiveness of Inkuiri-based Learning towards Mastering the Concept of Unsaturated Hydrocarbons in Undergraduated Students

Kurniawati, D., Masykuri, M., \& Saputro, S. (2016). Penerapan Model Pembelajaran Inkuiri Terbimbing Proses Sains dan Prestasi Belajar Pada Materi Pokok Hukum Dasar Kimia Siswa Kelas X MIA 4 SMA N 1 Karanganyar Tahun Pelajaran 2014 / 2015. Jurnal Pendidikan Kimia (JPK), 5(1), 88-95. ISSN 2337-9995

Lin, Y. I., Son, J. Y., \& li, J. A. R. (2016). Asymmetric translation between multiple representations in chemistry. International Journal of Science Education, 0693(March). https://doi.org/10.1080/09500693.2016. 1144945

Magfirah, A., Hidayat, A., \& Mahanal, S. (2019). Penggunaan Media Audiovisual pada Model Inkuiri Terbimbing terhadap Keterampilan Proses Sains dan Penguasaan Konsep IPA. Jurnal Pendidikan: Teori, Penelitian, Dan Pengembangan, 4, 96-103. http://dx.doi.org/10.17977/jptpp.v4i1.11 890

Margunayasa, I. G., Dantes, N., Marhaeni, A. A. I. ., \& Suastra, I. W. (2019). The Effect of Guided Inquiry Learning and Cognitive Style on Science Learning Achievement. International Journal of Instruction, 12(1), 737-750. Retrieved from https://eric.ed.gov/?id=EJ1201135

Masruroh, A., Ibrohim, \& Susilo, H. (2019). Pengembangan Pembelajaran Sains Berbasis Inkuiri Terintegrasi Nature of Science ( NoS ) dan Pengaruhnya terhadap Penguasaan Konsep. Jurnal Pendidikan: Teori, Penelitian, Dan Pengembangan, 4, 462-467. http://dx.doi.org/10.17977/jptpp.v4i4.12 257

Mattox, A. C., Reisner, B. A., \& Rickey, D. (2006). What Happens When Chemical Compounds are Added to Water? an Introduction to the Model-ObserveReflect-Explain (MORE) Thinking Frame. Journal of Chemical Education, 83(4),

622 https://doi.org/10.1021/ed083p622

National Research Council. (2000). Inquiry and the National Science Education Standards: A Guide for Teaching and Learning/ Center for Science, Mathematics, and Engineering Education. Washington, DC: National Academy Press.

Nugraha, M. G., Kaniawati, I., Rusdiana, D., \& Kirana, K. H. (2016, February). Combination of Inquiry Learning Model and Computer Simulation to Improve Mastery Concept and the Correlation with Critical Thinking Skills (CTS). In AIP Conference Proceedings 1708 070008. AIP Publishing LLC. https://doi.org/10.1063/1.4941181

Panasan, M., Nuangchalerm, P., \& Muang, A. (2010). Learning Outcomes of ProjectBased and Inquiry-Based Learning Activities Department of Curriculum and Instruction, Faculty of Education, Mahasarakham University, Mahasarakham $44000 \quad$ Thailand. Journal of Social Sciences, 6(2), 252$255 . \quad$ Retrieved from https://orcid.org/0000-0002-5361-0377

Pedaste, M., Mäeots, M., Siiman, L. A., De Jong, T., Van Riesen, S. A., Kamp, E. T., Zacharia, C. Z. \& Tsourlidaki, E. (2015). Phases of Inquiry-Based Learning: Definitions and the Inquiry Cycle. Educational research review, 14, 47-61.

Putri, P. N., Subandi, \& Munzil. (2018). Pengaruh Strategi Inkuiri Terbimbing dan Kolb's Learning Style terhadap Kemampuan Berpikir Tingkat Tinggi. Jurnal Pendidikan: Teori, Penelitian, dan Pengembangan, 3, 1656-1663. http://dx.doi.org/10.17977/jptpp.v3i12.1 2561

Rahmawati, R., Handayanto, S. K., \& Dasna, I. W. (2018). Pengaruh Learning Cycle 5 E terhadap Keterampilan Proses Sains Peserta Didik Kelas VIII. Jurnal Pendidikan: Teori, Penelitian, dan Pengembangan, 3(3), 286-290. 
Efectiveness of Inkuiri-based Learning towards Mastering the Concept of Unsaturated Hydrocarbons in Undergraduated Students

http://dx.doi.org/10.17977/jptpp.v3i3.10 624

Sesen, B. A., \& Tarhan, L. (2013). InquiryBased Laboratory Activities in Electrochemistry: High School Students' Achievements and Attitudes. Research in Science Education, 43(1), 413-435. https://doi.org/10.1007/s11165-0119275-9

Şimşek, P., \& Kabapınar, F. (2010). The Effects of Inquiry-Based Learning on Elementary Students' Conceptual Understanding of Matter, Scientific Process Skills and Science Attitudes. Procedia-Social and Behavioral Sciences, 2(2), 1190-1194.

Sulistyowati, E., Rohman, F., \& Ibrohim. (2020). Perangkat Pembelajaran Inkuiri Terbimbing Berbantuan Handout Berbasis Potensi Lokal Hutan Mangrove untuk Meningkatkan Kemampuan Berpikir Kritis dan Sikap Peduli Lingkungan. Jurnal Pendidikan: Teori, Penelitian, Dan Pengembangan, 5, 374-379.

http://dx.doi.org/10.17977/jptpp.v5i3.13 272

Supasorn, S., \& Promarak, V. (2015). Implementation of $5 \mathrm{E}$ Inquiry Incorporated with Analogy Learning Approach to Enhance Conceptual Understanding of Chemical Reaction Rate for Grade 11 Students'. Chemistry Education Research and Practice, 16(1), 121-132.

https://doi.org/10.1039/C4RP00190G

Sutrisno, Nanda, G. A. M., \& Widarti, H. R. (2020, April). The Effectiveness of Inquiry Based Learning with $\mathrm{OE}_{3} \mathrm{R}$ Strategy for Conceptual Understanding of Molecular Shape of High School Students'. In AIP Conference Proceedings 2215 (1), 020025. AIP Publishing LLC.

https://doi.org/doi.org/10.1063/5.00006 20.
Sutrisno. (2018). $\mathrm{OE}_{3} \mathrm{R}$ (Orientasi- EksplorasiEksplanasi-Elaborasi-Refleksi): Sebuah Inovasi Strategi Pembelajaran SainsKimia Berbasis Inkuiri. Prosiding Seminar Nasional Kimia dan Pembelajarannya (SNKP), 48-60, Malang: Universitas Negeri Malang.

Talanquer, V. (2011). Macro, Submicro, and Symbolic: The Many Faces of The Chemistry "Triplet". International Journal of Science Education, 33, 3741.https://doi.org/10.1080/0950069090 3386435

Villagonzalo, E. C. (2014, March). Process Oriented Guided Inquiry Learning: An Effective Approach in Enhancing Students' Academic Performance. In DLSU Research congress 2 (1), 1-6.

Wenning, C. J. (2005). Levels of Inquiry: Hierarchies of Pedagogical Practices and Inquiry Process. J. Phys. Tech. Edu, 3-11.

Retrieved from https://www.semanticscholar.org/paper/ Levels-of-inquiry\%3A-Hierarchies-ofpedagogical-and-

Wenning/a1bde8c3c70590833dd4fdca3 87cd07292fe6a88

Widarti, H. R., Sutrisno, Sulistina, O., \& Muchson, M. (2018). Uji Coba Implementasi Strategi $\mathrm{OE}_{3} \mathrm{R}$ (OrientasiEksplorasi-Eksplanasi-Elaborasi

Refleksi) Pembelajaran Dasar-dasar Kimia Analitik di Jurusan Kimia FMIPA UM. Prosiding Seminar Nasional Kimia Dan Pembelajarannya (SNKP), 61-68, Malang: Universitas Negeri Malang.

Zeidan, A. H., \& Jayosi, M. R. (2015). Science Process Skills and Attitudes toward Science among Palestinian Secondary School Students'. World Journal of Education, 5(1), 13-24. https://doi.org/10.5430/wje.v5n1p13 